\title{
宮島ホテル（税務講習所広島支 所）の接収と取り扱いについて
}

\section{A STUDY ON CONDITION OF PROCUREMENT OF MIYAJIMA HOTEL: TAX TRAINING CENTER, HIROSHIMA BRANCH}

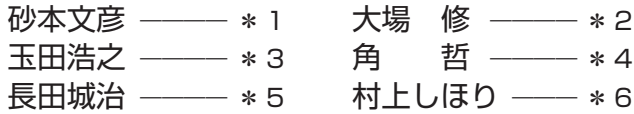

キーワード

宮島ホテル, 税務講習所広島支所, 接収, GHQ

\section{Keywords:}

Miyajima Hotel, Hiroshima Branch of Tax Training Center, Procurement, GHQ

Fumihiko SUNAMOTO $-* 1$
Hiroyuki TAMADA $-* 3$
Joji OSADA- -5

Osamu OBA $-* 2$
Satoru KAKU- $* 4$
Shihori MURAKAMI $-* 6$

This paper aims to clarify the details on procurement of Hiroshima Branch of Tax Training Center (former Miyajima Hotel) which had been national property. Hiroshima Prefecture had acquired the right to use and ordered repair of this building to renovate at foreign accommodation. During the transition of national property to non-national property under usage of B.C.O.F, stakeholders who had ownership and usage rights of this building and administrative organizations involved in the occupation policy had claimed various issues about procurement conditions.
1. はじめに

\section{1 研究目的}

筆者らはこれまで、第二次世界大戦後に占領軍に接収された施設 の建築的研究注 1) を継続してきたが、調査を進めるに従い接収とい う状況が単純に施設の管轄権が移管される事柄に留まらないことが 明らかになってきた。接収は、日本側、占領軍側の様々なステーク ホルダーが建築的交渉を行った具体相としてあり、この詳細を読み 解けば接収施設を巡る権利の主張や空間的な課題が明るみになろう。 本稿はその調査対象として、終戦当時、大蔵省が所有、管理して いた大蔵省税務講習所広島支所（かつての宮島ホテルの建築。後継 組織は現・税務大学校広島研修所)の接収について明らかにしたい。 同建物は 1917 年に外国人向け宿泊施設として新築された宮島ホテ ル（ヤン・レッツェル設計）であり、1944 年 4 月に広島財務局に譲 渡され、 5 月より税務講習所に転用されていた。詳細は後述するが、 終戦後、広島県はこれを改修してホテル再開を企図し、国に県への 所有権移転を働きかけつつ、同時に民間人を委託経営者に定めた。 だが、その手続きの最中の 1946 年 5 月 13 日、同建物は占領軍に接 収され、ホテルとしての一般営業は叶わなくなった。

税務講習所広島支所の接収状況の子細を見ていくと、所有権移転 交渉は接収後に本格化し、国 (大蔵省)、広島県、委託経営者に加え、 占領軍、占領政策関連機関など、数多くのステークホルダーが接収 された同建物に対する様々な認識と取り扱いを示していた。本報告 は、税務講習所広島支所の接収過程を詳細に分析することで接収を とりまく諸相をつまびらかにし、ひいては他の接収事例を分析する 研究視角をも見いだすことを目的とする。

\section{2 研究の史料と方法}

税務講習所広島支所接収に関する文書類は、広島県立文書館に「宮 島ホテル関係一件」として所蔵されている。「宮島ホテル関係一件」 は終戦直後から 1954 年までに作成された税務講習所広島支所接収 に関する 66 件からなる文書（表 1) であり、草案を含む公文書(日 本語)、添付の調達要求書 (英語)、そして関係機関間の往復書簡 (大 半は日本語) などが綴られている。戦前の宮島ホテルに関する文書は 宮島歴史民俗資料館に収められているが注 2)、戦後の接収について知 れる一次史料は「宮島ホテル関係一件」が唯一である。また、「宮島 ホテル関係一件」を参照した先行研究もない。戦後の改修工事は清 水組が行ない、現在の清水建設株式会社にも関連史料は無い注3)。

一方、建築物としての「宮島ホテル」に言及する文献はいくつか あるが、ほとんどはヤン・レッツェルの作品研究注 4) 注5) 注 6) に限ら れ、接収という局面を扱ってはいない。

本報告では、史料的価值が高いと考えられる「宮島ホテル関係一 件」に綴られた 66 件の文書の整理を進め、税務講習所広島支所の接 收に向き合ったステークホルダーの動きを把握する。文書は草案も 含まれていることから、適宜史料検証を経て分析を行う。また、「宮 島ホテル関係一件」は大蔵省税務講習所広島支所を宮島ホテルと呼 称する場合が多く、本報告でも特に留意するべきところ以外は宮島 ホテルと記すことにする。次章以降は煩雑を避けるため、「宮島ホテ ル関係一件」からの引用文書は表 1 に示す整理番号にて示す。

2. 宮島ホテルについて

まず接収前の宮島ホテルの諸経緯について整理しておきたい。宮

\footnotetext{
神戸女子大学家政学部家政学科 教授・博士 (工学)

( T 654-8585 神戸市須磨区東須磨青山 2-1)

京都府立大学大学院 教授・工博

大手前大学 准教授・博士 (学術)

名古屋市立大学大学院 准教授・博士 (工学)

郡山女子大学 講師・博士 (工学)

大阪市立大学大学院 客員研究員・博士 $($ 学術 $)$
}

Prof., Kobe Women's Univ., Dr. Eng.

*2 Prof., Faculty of Life and Environmental Sciences, Kyoto Prefectural Univ., Dr Eng.

Assoc. Prof., Otemae Univ., Ph.D

4 Assoc. Prof., Graduate School of Design and Architecture, Nagoya City Univ., Ph.D.

5 Lecturer, Koriyama Women's Univ., Dr. Eng.

*6 Visiting Researcher, Graduate School of Housing and Environmental Design, Osaka City Univ., Ph.D. 
表 1 「宮島ホテル関係一件」文書

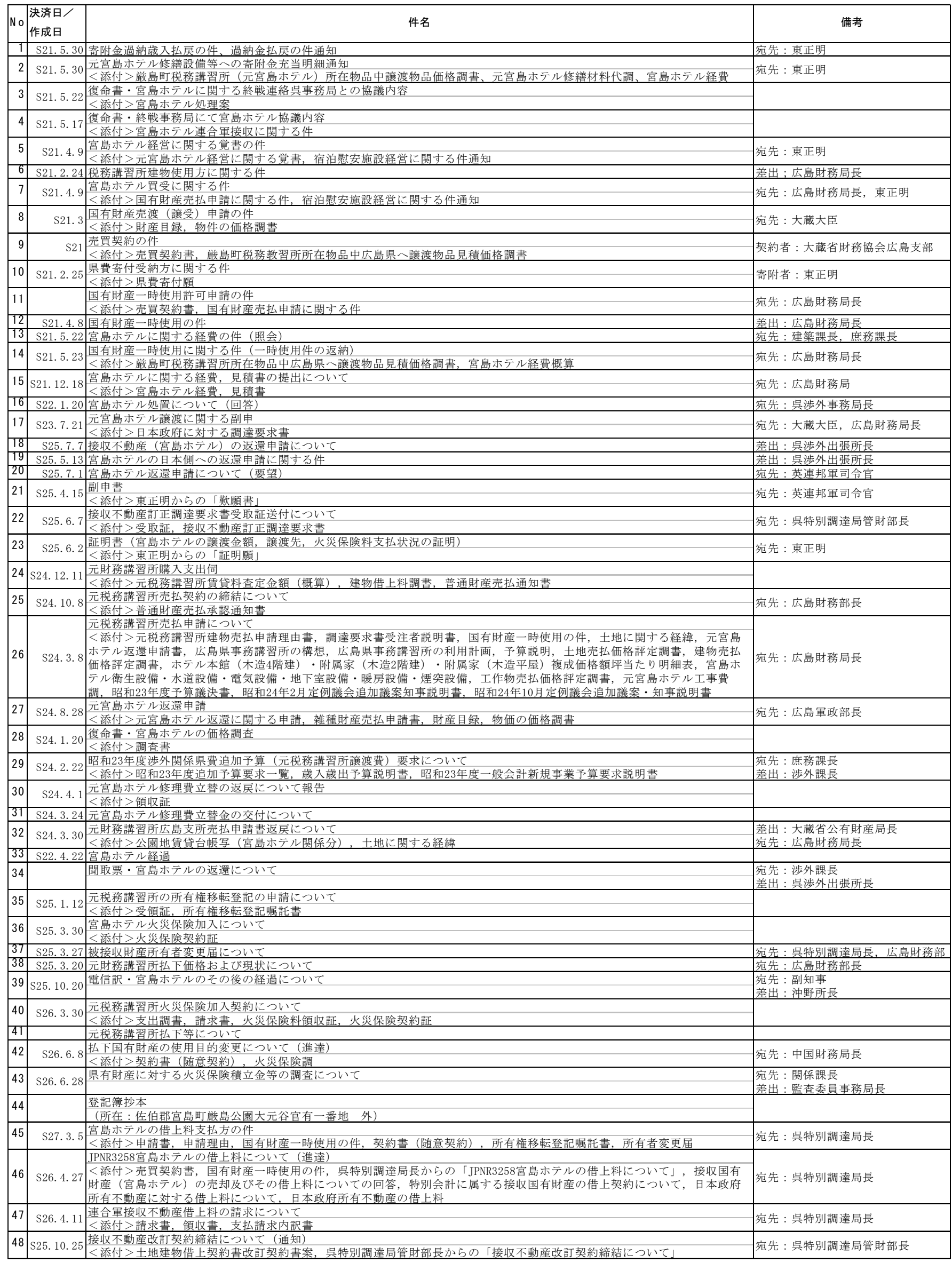




\begin{tabular}{|c|c|c|c|}
\hline 49 & $\mathrm{~S} 25.5 .27$ & $\begin{array}{l}\text { 土地建物借上契約について } \\
\text { <添付 }> \pm \text { 土地建物借上契約書 }\end{array}$ & 宛先：呉特別調達局管財部長 \\
\hline 50 & S25.3.24 & $\begin{array}{l}\text { 被接収財産の賃貸料について } \\
\text { <添付＞地建物賃貸借契約書，領収証書，呉特別調垟局不動産契約課からの「昭和25年度更新契約締結について」 }\end{array}$ & 宛先：呉特別調達局契約部長 \\
\hline 51 & S27.6.28 & 科目改定申請について & $\begin{array}{l}\text { 宛先 : 総務部長 } \\
\text { 差出 : 財政課長 }\end{array}$ \\
\hline 52 & S27.6.28 & $\begin{array}{l}\text { 土地建物売却代金に対する利子納付について（通知） } \\
\text { <添付 }>\text { 利息計算書 }\end{array}$ & 宛先：東正明 \\
\hline 53 & S27.5.30 & $\begin{array}{l}\text { 財産売却代金に対する利子徵収について } \\
<\text { 添付 }>\text { 元宮島ホテル売却代金に対する利息計算書 }\end{array}$ & 宛先：東正明 \\
\hline 54 & S27.4.8 & $\begin{array}{l}\text { 登記済証交付について } \\
<\text { 添付 }>\text { 受領証 }\end{array}$ & 宛先：梀宮島ホテル \\
\hline 55 & S27.4.20 & $\begin{array}{l}\text { 所有権移転登記嘱託について } \\
<\text { <添付 >所有権移転登記嘱託書, 家屋登録成申告書, 収入調書 }\end{array}$ & \\
\hline 56 & S27.4.1 & $\begin{array}{l}\text { 元宮島ホテルの登記変更について } \\
\text { <添付>侏宮島ホテルからの「元宮島ホテルの登記変更についての依頼文」，侏宮島ホテル定款，土地建物売却代金に対す } \\
\text { る利子納付につて（通知），利息計算書 }\end{array}$ & \\
\hline 51 & S28.2.23 & 元宮島ホテルの使用料補償金の配分方法について & \\
\hline 58 & S27.8.30 & $\begin{array}{l}\text { 宮島ホテル使用料について } \\
\text { <添付＞使用料補償契約書，土地借上契約書，土地建物借上契約書 }\end{array}$ & \\
\hline 59 & S26.7.20 & $\begin{array}{l}\text { 県有土地建物売却について } \\
<\text { <添付 }>2 \text { 月定例議会追加議案知事説明書, 契約書, 県報, 物件賃貸借契約書, 受領証 }\end{array}$ & \\
\hline 62 & S28.12.10 & $\begin{array}{l}\text { 宮島ホテルの経過調書提出について } \\
<\text { <添付＞宮島ホテル経過調書 }\end{array}$ & 宛先：中国財務局長 \\
\hline 63 & S28.3.23 & 元宮島ホテルの転売の経過について & 宛先：中国財務局長 \\
\hline 64 & S29.7.3 & $\begin{array}{l}\text { 宮島ホテル売買契約書原本貸付について } \\
\text { <添付＞契約書 (随意契約) }\end{array}$ & 宛先：呉調達局 \\
\hline 65 & & $\begin{array}{l}\text { 見積書（宮島ホテル改装工事費） } \\
\text { <添付＞喜島ホテル補修工事仕様書，宮島工事数量調書 }\end{array}$ & 差出：㑣清水組 \\
\hline 66 & S21.5.22 & $\begin{array}{l}\text { 宮島ホテルに関する経費の件 } \\
\text { <添付＞工事設計書,宮島ホテル補修工事仕様書,見積書,付近地形図,本館平面図,敷地実測図 }\end{array}$ & \begin{tabular}{|l} 
差出: 内部部長 \\
宛先：建築課長
\end{tabular} \\
\hline
\end{tabular}

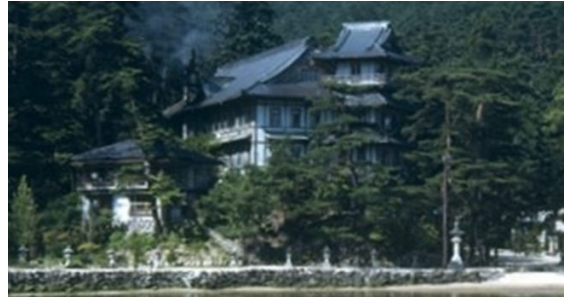

図 1 宮島ホテル外観

The Australian War Memorial 所蔵 (P05195. 038 をサイズ修正)

島ホテルが位置した広島県厳島は日本三景の地として名を馳せ、明 治末から大正期には広島県による観光・公園行政の対象地となり、 財界人発起により株式会社宮島ホテルが 1912 年に設立された。会社 設立当初から外国人向け宿泊施設の整備が目論まれ、県知事寺田祐 之の関与のもとでヤン・レッツェル設計による新たなホテル建築が 1917 年に竣工した。それは知事の前任地である宮城県の松島パーク ホテルをレッツェルが設計したことに由来している。ふたつのホテ ルはいわゆる日本趣味を帯びた洋式設備を持つ木造建築で、レッツ エルは広島県物産陳列館（いわゆる原爆ドーム）設計でも著名であ る。ホテルは洋室 20 室、和室 2 室の合計 22 室、総収容人員は 40 名だった。開業後のホテル営業成績は芳しくなく、幾度か売却に迫 られ、特に戦時中は極端に悪化、1944 年 4 月には広島財務局に譲渡 され、同年 5 月より大蔵省税務講習所に転用された注7) 注 8)。

終戦後は枕崎台風により建物被害を受けて利用されずにいたが、 広島県が占領軍向けのホテルとして再開するため改修を企図し、改 修中の 1946 年 5 月 13 日に接収された。

接収に前後して実施された工事内容は、「宮島ホテル関係一件」に 付された見積書よりある程度、明らかになる。見積書は清水組と押 印されており、そこにはトイレの洋式化、室内仕上げ変更、ドア開 閉方向の変更、雨水漏水対策、水源地工事などが記されている (No. 65, 66)。改修の方針は、設備上の一層の外国人対応と枕崎台風
被害での破損個所補修である。図 1 は接収時の外観写真である。

\section{3. 接収に至る経緯と諸課題の発生}

1946 年 5 月 13 日の接収後、広島県庶務課市川士郎は、 5 月 22 日 に終戦連絡呉事務所を訪れ、「宮島ホテル処理案」について協議を行 い、その出張復命書（No. 3）にはやや複雑な事情を報告した。

\section{一、経過}

五月十三日付連合軍より元宮島ホテル接収命令書を終戦事務局に 受けたるに付其の結果広島県涉外課呉事務所長冨士盛彰氏五月二十 一日来県に付協議せる結果案を以て交渉す

交渉先 服部事務局長立会 冨士盛事務所長

一、県側の意向説明

宮島ホテルは現在国有財産にして県に買受手続中なるも大蔵省に 於ける手続相当長時日を要する処なるを以て差当り家屋仮使用の申 請を為し財務局より一時使用の承認を受けたるを以て本年四月十五 日以降進駐軍の宿泊娛楽慰安等の設備をなさしむる為呉市東正明に 財産無償貸与をなしたるものなり

此の財産は国有財産を県有財産として譲受け県は国立公園たる宮 島に観光に関する県有の施設を目的とせるものなるも連合軍進駐の 状況に鑑み差当り之等の宿泊娛楽等の設備は最も急を要するを以て 前述の如き措置を執りたるものなり

然るに連合軍より接収せられるに至れる現在に於ては東正明は宿 泊慰安等営業に依り収益を得る見込を失い（後略）

宮島ホテルは終戦前に国有化されていたが、戦後、県による買受 手続や一時使用、さらに民間人への財産無償貸与などがなされて権 利関係が輻輳していたのである。接収前の経緯から整理したい。

終戦当時、広島県では県警察部特別高等警察課 (以下、特高課) が 占領軍対応の事務を掌握していた。1945 年 10 月頃、特高課長太宰 
博邦が使用されずにあった宮島ホテルを外国人向けの慰安・宿泊・ 娛楽施設とすることを着想、その旨を所有者である大蔵省広島財務 局に申し出た。同時に県の建築課長松井にも話を通し (No. 7, 16)、さ らに委託経営者として呉市在住の「芸予観光協会代表」東正明を見 出した。東には当面無償貸与することにしたという (No. 5)。

広島県は財政難にあったことから、将来のホテル取得に関する資 金は東から寄付金 20 万円を県に支払わせて、そのまま大蔵省に支払 う計画だった(No. 6)。ただ、宮島ホテルの建物は枕崎台風で被災し ておりそのまま使用できないことから、太宰は大阪の清水組を訪补 て改修工事の発注を行ない注 9)、改修工事費もまた東に直接負担させ たという(No. 31) 注 10)。以上の経緯もあって、「之れが財産は、永久 に東正明に使用せしむるの必要ある」との認識を示している (No. 6)。 特高課長太宰の主導のもと、4 月 15 日に県は国有財産である宮島ホ テルの一時使用の承諾を得て、占領軍向けホテル経営のために民間 人「呉市東正明」に「財産無償貸与」をなし、東は寄付金と改修工 事費を支払った。同時に太宰は国に払い下げ手続き開始を求めてい る。この状況に 1946 年 5 月 13 日の接収がなされたのである。

実はこの経緯が広島県庁内で「発覚」したのは、1946 年初め、清 水組から県財務当局に工事請求書が送られてきてからだったという (No. 7)。県庁内にその請求内容について知るものがおらず庶務課長 日原は調查を開始、特高課長太宰や建築課長松井の動きを把握し、 大蔵省広島財務局からも聴取を行って、前述の経緯が把握されたの である。なぜ県庁内に事情を知る者がいなかったかといえば、特高 課長太宰と建築課松井は請求書到着時に既に公職を追放されており、 また引き継ぎも行われていなかったためだという。

結果、県は事後的に「既にこれまでに特高課長が承諾を得て宮島 ホテルを修理していた工事の請負費も措置せ齐ばならぬ」ことにな り、善後策を広島財務局と協議、ここで「将来これを県に譲受ける こと」と「差当りの措置として宮島ホテルの一時使用の許可を受け ること」注11)、そして「修理を行う」ことが承諾された(No. 62)。た だ、このことは財務局から広島県が引責すべきだという認識が示さ れたものであろう。

県も清水組からの請求金額を支払うことはできず、「県の官吏、吏 員等で斯様な宿泊、慰安施設を直営する能力はない」(No. 62)ため、 委託経営者に内定していた東に支払いも負わせることにした。

寄付金を除いて東が直接投資を行った金額は、接収 2 日後の 1946 年 5 月 15 日時点で、建物改修工事 351,000 円、水源地新設工事 107, 000 円、椅子、手洗い等の物品費 41, 588 円、合計 499, 588 円に なった (No. 16, 65)。このうち、建物改修工事と水源地新設工事の 458,000 円は清水組に支払い、椅子、手洗い等の物品は 1946 年 3 月 16 日に県が国から購入したものをそのまま東が同額の 41, 588 円で 購入したものである (No. 62)。不動産の所有関係としては、改修前の 原形の国有財産の建物に、個人資産の改修工事部分が付帯した状態 になり、加えてその室内には個人資産の物品が置かれていた。よっ て、国から県への不動産払い下げ手続きは難航したまま 5 月 13 日の 接収を迎えていたのである。調達要求書 (Procurement Demand/PD) は「東正明の財産である如く」東正明の名義で出されており、それ は実質の経営者が東とみなされたためだったという（No. 26）。

ところで、国有財産の接収の場合は使用料が発生しないが、私有 財産接収の場合は使用料が計上されて、所有者は使用料を得ること
ができた(詳細は後述)。ただ、宮島ホテルの PD は東名義で私有扱い だったにもかかわらず、実際の接収の局面においては全ての財産が 国有扱いとされ、東に使用料が支払われなかった。つまり、東は特 高課長が実質的な発注をした改修費用を負担し、調度品を購入して 499, 588 円を支払い、さらに県に寄付金 20 万円を納めたうえで、接 収によりホテル営業ができないばかりか、ホテル一式が国有財産と みなされて使用料も受領できない状態に陥ったのである注 ${ }^{2)}$ 。

\section{4. 接収中における各種交渉}

東の不利益な状態を解消するため、接収中にもかかわらず、広島 県、大蔵省広島財務局、東らは宮島ホテルの不動産・動産の権利関 係の整理に取り組んだ。当初は認められなかった使用料も得ること になっていった。この交渉過程には接収不動産・動産に対する様々 な認識と取扱いが示されていて、本章ではその子細を分析する。

\section{1 寄付金と改修費等の精算}

多額の金銭負担のみを強いられた東は、関係方面に陳情を繰り返 した。県に納付した寄付金 20 万円については県の迅速な対応により 1946 年 5 月 31 日に精算が行なわれ、県が受け取る心゙き金額と相殺 して、東に 118, 412 円が支払われた (No. 33)。

続いて東が負担した改修等費用については、原形の国有不動産と 東支払いによる改修部分が一体化していることから、県は不動産所 有者である国こそが手当てするべきと主張し、広島財務局や呉終戦 事務局と交渉を重ねた。その後、広島財務局から県に対し、国有財 産に東の私有財産が合わせて存在していることは適当ではないとし て、国が県に工事実施を命じて修繥したかたちをとることで (No. 33, 62)、修理費用を国が県に支払う旨の連絡がなされた。つま り、改修部分の私有財産を国有化することを目論んだのである。そ して 1947 年 4 月 21 日、国から 458,000 円が県に支払われ (No. 33)、 県副知事がこれをそのまま東に渡そうとしたところ、東は戦後イン フレを反映した金額ではないと、受領を拒否した（No. 16, 30,62）。 さらに「財務局の扱に不信非難」をしたという（No.62）。

宮島ホテルの経営を目指していた東にしてみれば、物価上昇分の 加算が無いことも反対理由であったろうが、県に収めた寄付金は既 に清算済みのところに改修費等まで受け取ってしまえば、宮島ホテ ルに対する請求権のほとんどを失い、ホテル委託経営者として内定 している立場も危うくなるとの判断もあったと思われる。実際、こ の時、東は改めて宮島ホテルの譲渡希望を表明している。

しかし、2 年ほど過ぎた 1949 年 3 月、東は修理代返還相当金 458, 000 円に、その間の利息分としてわずか 13,052.12 円を加算し た 471, 052.12 円を受領し、改修費等の清算を終えた。受け取り者は 母の東チヨノだった（No. 31）。一転して、戦後インフレをほとんど 勘案しない金額での妥協的精算を東が受け入れたのは、ちょうどこ のころ、県議会においてホテルの不動産を東に譲渡する方針が示さ れており注 ${ }^{13)}$ 、むしろ接収前の支払い関係を精算した方が、後の不 動産取得に有利に働くと東は判断したのではないかと思われる。

\section{2 不動産の国から県への払い下げと接収物件に示された認識}

これに並行して国から県への払い下げ交渉が行われ、県営繥課は 宮島ホテルの評価額を、1948 年 8 月に $3,802,520$ 円と見積もり (No. 27, 28)、交渉の本格化に備えていた。その後、広島財務局は県 と譲渡交渉に入り、県は財産費として 385 万円を計上したが (No. 26)、 
広島財務局は 4, 011, 867 円を提示、終戦処理による経費も加算する べきとして平行線をたどった注 ${ }^{14)}$ 。結果、翌年になって広島県は大 蔵省の主張する 4, 011, 867 円を受け入れ、1949 年 9 月 29 日に払い 下げ契約が締結、10 月県議会で購入支出伺が出された。大蔵省への 納入は 1949 年 12 月 21 日付とされている (No. 37) 注 15)。こうして宮 島ホテルの不動産は県所有となった。

国から県への譲渡については多くの否定的な認識が示された。例 えばこの手続きの過程の 1949 年 3 月 30 日に、大蔵省の公有財産局 長は広島財務局長に宛てて、この売払申請書を接収中物件の譲渡は 正式返還後でなければできないことを理由に「詮議困難」として差 し戻していた (No. 32)。さらに県渉外課がまとめたNo. 41 によると、 払い下げの際に GHQ の承認を得たかの事実関係について、大蔵省管 理局国有財産第二課長松田はその承認は文書でも口頭でも受けてお らず、事務の実施は広島財務局と県の強い希望により実施したとし、 「軍側に話を持って行ったならば、反対され払下は出来て居なかっ たであろう」とも記している。また、GHQ からも特別調達庁を通じ て「何故接収中のものを払下たか、之は違法ではないか」と問い合 わせがあり、「一応大蔵省としては謝意を述へ、払下げたことについ ては国内法では違法ではない」ことを説明し、その後 $\mathrm{GHQ}$ から再度 の連絡がなかったことから GHQ はこれを「認めた模様」と理解した とした。ただ、松田は「今日新に（GHQの；引用者注）承認を受ける ことは大蔵省としては自信が持てない。却って反対に払下げ取消し の措置を強要せられるかもしれない」との認識を示している。県所 有になったことで使用料を得ることはできるかについては、使用料 不払いは「大蔵省は実の所反対」ではあるのだが、「接収当初国有財 産であった事は間違いなく県に対し当初厚意的に払下げたものであ るから其の点を了解願って…HQ 事にも理屈のあることであるから何とか此の際少し待ってみる方が 良い」と、置かれた立場の難しさを吐露している。こうした状況に ついて、特別調達局不動産課山崎は、接収中の不動産の譲渡は国内 法では認められること、県に使用料を払う必要があることなど松田 と同様の見解を示したが、次のような $\mathrm{GHQ}$ の考えも示している。

日本政府所有の不動産を無料で使用することは国際法の規定及び 陸戦の法規に依り連合軍に与えられた権限に属し、日本の法律には 支配されない。依って日本政府所有の不動産に対する借上料は支払 わない。これが意見は最初呉の調達官より $\mathrm{GHQ} に \square \square$ (判読不能)」 申せられ、GHQ 係官はこれと同一意見で両者の意見は今日完全に一 致している

加えて「専売公社、国有鉄道所有財産で接収されたものも別添の 通り使用料は一切支払われていない」こともあり、山崎は、接収当 初に国有財産であったものは払い下げられても使用料は支払われず、 「正式県の所有が認めらえるのは講和後」との認識を示していた。 実際、調達部による「日本政府所有財産ノ調達二関スル方針」(1951 年 10 月 6 日) (No. 45)には、国有財産が接収されたときは借上料は無 料であることとともに、接収された国有財産がその後個人財産にな った場合にも「その売却は占領軍が該不動産を借上料無料の建前で 接収する権利に何の影響を与えるものではない。その売却は占領軍 の接収権を条件としてなされる」と、見解が示されている。
こうして国から県に払い下げられ、さらに東に払い下げられる一 連の方針の第一段階が終わったのだが注 ${ }^{16)}$ 、払い下げは関連各方面 への調整をあえて行わず実施されていたことがわかる。なおかつ、 関係機関からは接収中不動産の袞渡に関する疑義が示され、本来は 計上可能な使用料を得ることも困難であるとの認識が示された。

\section{3 使用料計上と不動産の県から東正明への払い下げ}

講和までは使用料計上は避けるよう関連機関が GHQ に忖度するな かで、県は講和を待たず使用料請求の動きを活発化させていった。 1950 年 3 月 23 日には、広島県に譲渡された期間（1949 年 12 月 21 日から 1950 年 3 月末日迄) の使用料を遡及して請求する交涉を開始 し、この時は受領に至らなかったが、1950 年 9 月 19 日には呉特別 調達局と土地建物借上契約を締結、さらに 10 月 25 日には賃借料契 約を 4 月 1 日まで遡及して結ぶこととなり (No. 54)、1950 年度 (1950 年 4 月 1 日〜 1951 年 3 月 31 日）の使用料を月額 32,587 円にて得る ことになった (No. 46, 47, 54,61)。加えて未受領の 1949 年 12 月 21 日〜1950 年 3 月末日の使用料も遡及して受領し(No. 54)、所有権が 東に移転する 1952 年 4 月 6 日までの使用料も受領した (No. 60) 注 17 。

1951 年 4 月の文書 (No. 46 ) によると、この使用料請求にあたり県 知事は呉特別調達局長に宛てて、接収時点で実質的な使用権は県に あり手続きが遅れていただけで、県が所有権を得れば使用料請求の 権利があると伝えており、これも交渉を前進させたと考えられる。

県の動きはこれに留まらず、東への所有権移転に及んだ。県は 1950 年 6 月 2 日に、東が県に 4, 011, 867 円を納入すれば所有権を譲 渡する方針を決定し(No. 22)、1951 年 6 月 8 日には宮島ホテルを県 職員研修施設に利用するとした契約内容をホテルに変更する旨を中 国財務局に申請 (No. 42)、そして 1951 年 7 月 20 日に県は東と宮島ホ テル一式の譲渡契約をなした(No. 55) 注 18)。この時点では、6月 8 日 に申請した使用目的変更申請は中国財務局と合意されていない。

東は 1951 年 8 月から 1952 年 4 月にかけて購入費用を分割払いし (No. 51, 52, 53)、最終支払の完了した 1952 年 4 月 7 日、東チヨノが 代表取締役を務める株式会社宮島ホテル (呉市公園通 3 丁目 1 番地) に所有権移転がなされた（No. 55, 56, 62）。

$\mathrm{GHQ}$ 一の刺激を避けるように関連機関が求めていたにもかかわら ず、県がなした迅速な対応は再び疑義を招いた。1952 年 7 月 2 日、 中国財務局長森岡謹一郎は県知事大原博夫に対し、10 年間の用途指 定(講習施設)をなして県に売買契約をしたのに、東へホテルの利用 を前提に転売したことは違反であり、その経緯の説明を求めた (No. 63)。一年以上経過した 1953 年 9 月 30 日に県は回答した (No. 62)。 紆余曲折は経たが、1952 年 4 月 7 日に宮島ホテルは東の単独所有 となり、それ以前に県が得た使用料は、県と東の財産持ち分比率に より配分された(東は調度品等を所有していた)。例えば 1950 年 4 月 1 日から 1951 年 3 月末日までの年間使用料は $1,991,855$ 円で、広 島県に 1,228, 817 円、東には 763, 3038 円が配分され (No. 57, 58)、所 有権が東に移転した 1952 年 4 月 8 日以降は全額が東に納入された。 こうして複雑になっていた不動産・動産の所有権と使用権、金銭支 払いの問題を逐次解決していき、接収さえ解除されれば、東による ホテルの一般営業が再開する見込みとなったのである。

だが、1952 年 8 月 31 日、宮島ホテルは接収するオーストラリア 軍の失火より、全焼した。焼失後、請求交涉が再び行われ、1948 年 8 月 1 日から東に所有権があり県に貸与したかたちとなっていた調 
度品類（化粧台他 20 件）に対する備品使用料月額 11,775 円が計上 され、1953 年 2 月 27 日、 435,708 円が県から東に支払われた (No. 59)。 もともと東に所有権のある調度品が県に「貸与」されていた期間の 請求権に対する議論は、「宮島ホテル関係一件」には確認できないこ とから、予測の域を出ないが、こうした事後の対応は焼失補償の意 味合いも含んでのものではないかと思われる。

調達庁不動産部管理課作成「英連邦軍使用施設調查表 昭和 29 年 1 月 1 日現在」によると、英連邦軍が使用する宮島ホテル所有施 設（JPNR3258）には、建物として「敷 485」坪、「延 254.90」坪、契 約件数は 4 件あり、月額借上料は 42,687 円と記されている。焼失後 の 1954 年 1 月にも使用料が支払われていたことがわかる。東は 1954 年 7 月、ホテルの焼失に関し国を相手取り損害賠償請求訴訟を開始、 東京地方裁判所にて審理が行われたという(No. 64) 注 19)。

\section{5.まとめ}

宮島ホテル（大蔵省税務講習所広島支所）の接収状況を見ていく と、国 (大蔵省ならびに広島財務局)、民間委託経営者となっていた 東正明、両者に働きかけを行った広島県 (特高課、庶務課、建築課)、 占領軍、特別調達庁、呉特別調達局、軍政部、そして施工業者など、 接収という状況に向き合い続けた多くのステークホルダーがいて、 それぞれが接収建物に向けた認識とその取り扱いは様々であったこ とがわかる。特に、所有権、使用権そしてそこから発生する使用料 を定める契約のありかたなど、空間利用を巡る権利と評価について の主張が輻輳しながら接収という継続的状況が成立していた。また、 接収においては $\mathrm{GHQ} の$ 存在が過大視されがちであるが、宮島ホテル では広島県などの交渉態度が事態の推移に大きく影響を与えていた ことがわかった。

本報告にて扱った宮島ホテルは一般的な事例ではないかもしれな い。だが、接収を取り巻く様々な空間利用上の権利と評価の要点を 一事例から多面的に確認できるものと言え、全国に無数にあった他 の事例も同様に接収／交涉（利益関係）の場として分析できる可能 性がある。戦後に接収された建築物の事例研究を加えていく上での 検討課題が明らかとなったと考える。特に国有財産とそれ以外の財 産（自治体所有、民間所有）は、使用料の発生と請求権の確認にお いて取扱いの差が大きいという事実は重要である。

謝辞 NP0 法人歴史建築保存再生研究所理事松波秀子氏、清水建設 株式会社コーポレートコミュニケーション部畑田尚子氏に御協力を 頂きました。本研究は、JSPS KAKENHI Grant Number JP26249086(代 表: 大場修)、JP16K14367 (代表: 砂本文彦)、JP19H02332(代表 : 角哲) の助成を受けたものです。

\section{注}

注 1) 村上しほり他: 占領下日本における部隊配備と占領軍家族住宅の様相、 日本建築学会計画系論文集、739 号、pp. 2441〜2450、2017.9 ほか。

注 2) ホテル支配人を務めた森啓造が宮島町立宮島歷史民俗資料館に寄贈した 約 100 点の資料がある。高橋修三「資料紹介一「宮島ホテル」関係資料 一」、宮島の歴史と民俗、No. 8、pp. 29〜112、1991

注 3) 2017 年 2 月清水建設株式会社コーポレートコミュニケーション部に確認。 注 4) ヤン・レッツェルの助手を務めた市石英三郎: 原爆ドームとヤンレッル、

建築雑誌、1002 号、pp. 14〜15、1968。
注 5) 菊楽忍 : ヤン・レツル再考一書簡集から建築活動をたどる、広島市公文 書館紀要、25 号、広島市公文書館、pp. 19～25、2012. 6 は宮島ホテルの 計画・受注を 1913 年、着工を 1916 年 4 月、竣工を 1917 年 7 月と指摘。 注 6) 佐藤重夫 : 広島原爆ドームとヤンレツル、日本建築学会大会学術講演梗 概集、pp. 819 820、1968

注 7) 注 2) と同じ。

注 8) No. 26「土地売払価格評定調書」（1949 年 3 月 10 日）によると、土地は 1944 年 12 月 9 日に株式会社宮島ホテルから大蔵省税務講習所が 28,360 円で購入し、1946 年 3 月 23 日に大蔵省が引き継いだとある。

注 9）No. 65 にこの時の清水組作成による見積書が綴られていて、改装工事の みの付帯設備、装飾設備は含まずに総額 215,000 円の工事だった。

注 10） 1953 年にまとめられた No. 62 には「発注者は広島県知事の名義」とさ れているが、正しくは東正明の直接契約である(No. 7)。また同様に 4 月 15 日に一時使用の承諾を得て県が修績にとりかかったとするが、No. 7 な どには接収に先立って工事が進捗していたことが示されている。

注 11) No. 13 に綴られている 5 月 24 日「国有財産一時使用二関スル件」によ ると、一時使用許可を申請したのは 4 月 5 日、許可を得たのは 4 月 8 日 とされる。ちなみにNo. 13 は一時使用許可返納願であり、接収されたた めに一時使用許可を返納しようとしたものだった。接収解除後は「譲受 け下さる様」にも申し添えられていた。ただし、実際には一時使用許可 は返納されてはいない。

注 12) 日本国内には接収された多くのホテルがあり、占領軍が直営する場合 と元々のホテル経営陣（従業員）が業務委託を受ける場合があった。宮 島ホテルは東正明が「委託業者」とされることはなく占領軍が直営した。 長田城治他：占領下日本におけるホテルの接収形態とその動向 占領下 日本の都市・住宅に関する研究 その 15 、日本建築学会大会学術講演梗 概集 建築歴史意匠、2018 は接収された全国のホテルの整理をしている。

注 13) 1949 年 2 月 28 日県定例議会は宮島ホテルを財務局から購入して東正明 に譲渡する方針を確認 (No. 26)、購入金額は 385 万円とされた (No. 59)。

注 14)この 4, 011, 867 円は No. 26「元税務講習所売払申請について」に経られ ている評定調書 (大蔵省作成)に示された土地 28,360 円、建物 3,714, 763 円、付属施設 268, 744 円の総計である。

注 15) 呉特別調達局長らに宛てた「被接収財産所有者変更届」（No. 37）では 1949 年 12 月 21 日付であるが、No. 24, 35 は 12 月 10 日に納入されたとし ている。借り上げ費用の発生は 12 月 21 日付であり前者が正しい。

注 16) 国への払い下げ交涉に並行して県や東は英連邦軍、呉渉外出張所、軍 政部等に接収解除要請も繰り返し、全て断られた (No. 18〜21, 27, 34)。

注 17) 1951 年 4 月 2 日に特別調達庁は使用料を無料にす心゙きとの見解を示し (No. 46)、4月 10 日には呉特別調達局も「国有財産 ᄏ政府機関以外へ売 却スルコトハ認メラレヌ」としたが (N0.46)、使用料は支払われ続けた。

注 18) 国から譲渡されてからの期間 (1949 年 12 月 21 日以降の期間)に応じた 利息 $(327,330$ 円)を 4, 011, 867 円に追加した総額 4, 339, 197 円が東に請 求された (No. 51, 52, 53)。

注 19)これ以降については調査対象外とした。

[2019 年 5 月 13 日原稿受理 2019 年 7 月 17 日採用決定］ 